\title{
25. SEDIMENT VELOCITIES AND DEEP STRUCTURE FROM WIDE-ANGLE REFLECTION DATA AROUND LEG 116 SITES 1
}

\author{
Jonathan M. Bull ${ }^{2}$ and Roger A. Scrutton ${ }^{2}$
}

\begin{abstract}
The reduction of six wide-angle reflection profiles shot within the two fault blocks visited by Ocean Drilling Program (ODP) Leg 116 in combination with the ODP sonic logs has produced a velocity-depth structure for this area. The sediment velocity increases from $1.6-1.7 \mathrm{~km} / \mathrm{s}$ in the near surface to $3.4-3.5 \mathrm{~km} / \mathrm{s}$ immediately above basement with a velocity gradient of $0.75 / \mathrm{s}$. A depth converted seismic reflection profile suggests that the pre-deformational basement surface was similar to the abyssal hill topography developed in the Pacific Ocean. A velocity for the top of oceanic layer 2 of $4.1 \mathrm{~km} / \mathrm{s}$ was identified as layer $2 \mathrm{~A}$. Assuming a velocity gradient of $0.7 / \mathrm{s}$, an estimate of layer 2 thickness was obtained of $1.5 \mathrm{~km}$. It is possible to interpret residual depth anomalies in terms of a layer 3 that may be thinner than for normal oceanic crust.
\end{abstract}

\section{INTRODUCTION}

In October 1987 RRS Charles Darwin visited the area of the ODP Leg 116 sites as part of an Edinburgh University cruise (CD 28) investigating the structural style of intraplate deformation and the geological and tectonic history of the Afanasiy Nikitin Seamount. During the survey around the drill sites, vertical incidence single and multichannel seismic reflection, gravity, magnetic, bathymetric, and wide-angle reflection data were collected. The results from the wide-angle reflection survey are presented here with the aim of describing the velocity-depth structure in sediments and basement around the ODP sites, seeking any lateral variations of velocity within the fault blocks related to tectonic history, and discussing the geological and tectonic implications of these features.

The wide-angle reflection data were collected concomitantly with vertical incidence reflection profiles, using disposable sonobuoys on east-west tracks parallel to the structural grain (Fig. 1). Data quality on the six sonobuoy profiles was highly variable and the picking of wide-angle events was made difficult by the fairly monotonous sediment sequence of silts and sands that gave few discrete strong reflections that could be traced for far along profile. For the same reason it was also difflcult to correlate velocity changes selected from these profiles with any lithologic variations noted from the ODP data. Some details of the velocity structure within the fault blocks were resolved, however, and the the top of oceanic layer 2 produced strong reflected and refracted arrivals on most of the sonobuoys, which facilitated a consistent measurement of a mean sediment velocity above basement. Good depth conversions for basement followed from this sediment velocity data.

\section{DATA REDUCTION AND RESULTS}

The sonobuoy data were digitized and then inverted using a least-squares $\mathrm{T} 2-\mathrm{X} 2$ program to give r.m.s. velocities and then interval velocities and layer thicknesses. The structure produced was confirmed by forward modeling using a ray-

\footnotetext{
${ }^{1}$ Cochran, J. R., Stow, D. A. V., et al., 1990. Proc. ODP, Sci. Results, 116: College Station, TX (Ocean Drilling Program).

2 Department of Geology and Geophysics, University of Edinburgh, West Mains Road, Edinburgh EH9 3JW, Scotland.
}

tracing program to iteratively adjust the calculated traveltimes until agreement was reached with the observed travel times. Velocity gradients rather than constant velocities within layers in the sediments could also be investigated in this way. For a more detailed discussion of sonobuoy data reduction and sediment velocity determination see Le Pichon et al. (1968), Houtz et al. (1970) and White (1979). A summary of the results from each of the sonobuoys is given in Table 1.

Of the six sonobuoy profiles, those in the center of the fault blocks $(1,4,8)$ gave the best records. Those shot closer to the uplifted edges of the fault blocks $(3,5,6)$ may have been degraded by the combination of steep out-of-plane dip and increased fracturing up-block to give poorer, less decipherable profiles. However, despite these problems, there is a suggestion from mean sediment velocities above basement that velocities decrease slightly southward in each fault block, perhaps reflecting the increased fracturing toward the principal faults.

Using the fact that the calculated interval velocities are actually the mean velocities within the layers, an estimate of the average sediment velocity gradient above basement was obtained by plotting the interval velocities at a depth corresponding to the mid-points of the layers and then fitting a least-squares first-degree polynomial to the data. The straight line is of form $V=V_{0}+a H$, where $V_{0}$ is the instantaneous velocity at depth $H, V_{0}$ is the sediment surface velocity, and $a$ is the average sediment velocity gradient. For the interval velocities determined from the six sonobuoys, $V_{0}=1.73 \mathrm{~km} / \mathrm{s}$ and $a=0.75 / \mathrm{s}$. This gives an estimate of the sediment velocity immediately above basement of $3.4-3.5 \mathrm{~km} / \mathrm{s}$, which agrees well with estimates of the base-sediment velocity from nearby published sonobuoy results (Curray et al., 1982; Stein and Weissel, in press). Using this simple velocity function, the north-south single-channel reflection profile shot by the Charles Darwin through the ODP sites (Line A, Fig. 1) was depth converted (Fig. 2). A fully processed and migrated multichannel reflection profile along this line is shown in Figure 3.

Two principal refracted arrivals were recorded in the sonobuoy data, one of velocity $4.0-4.1 \mathrm{~km} / \mathrm{s}$ from the top of basement and another of $6.8-6.9 \mathrm{~km} / \mathrm{s}$, presumably from the 


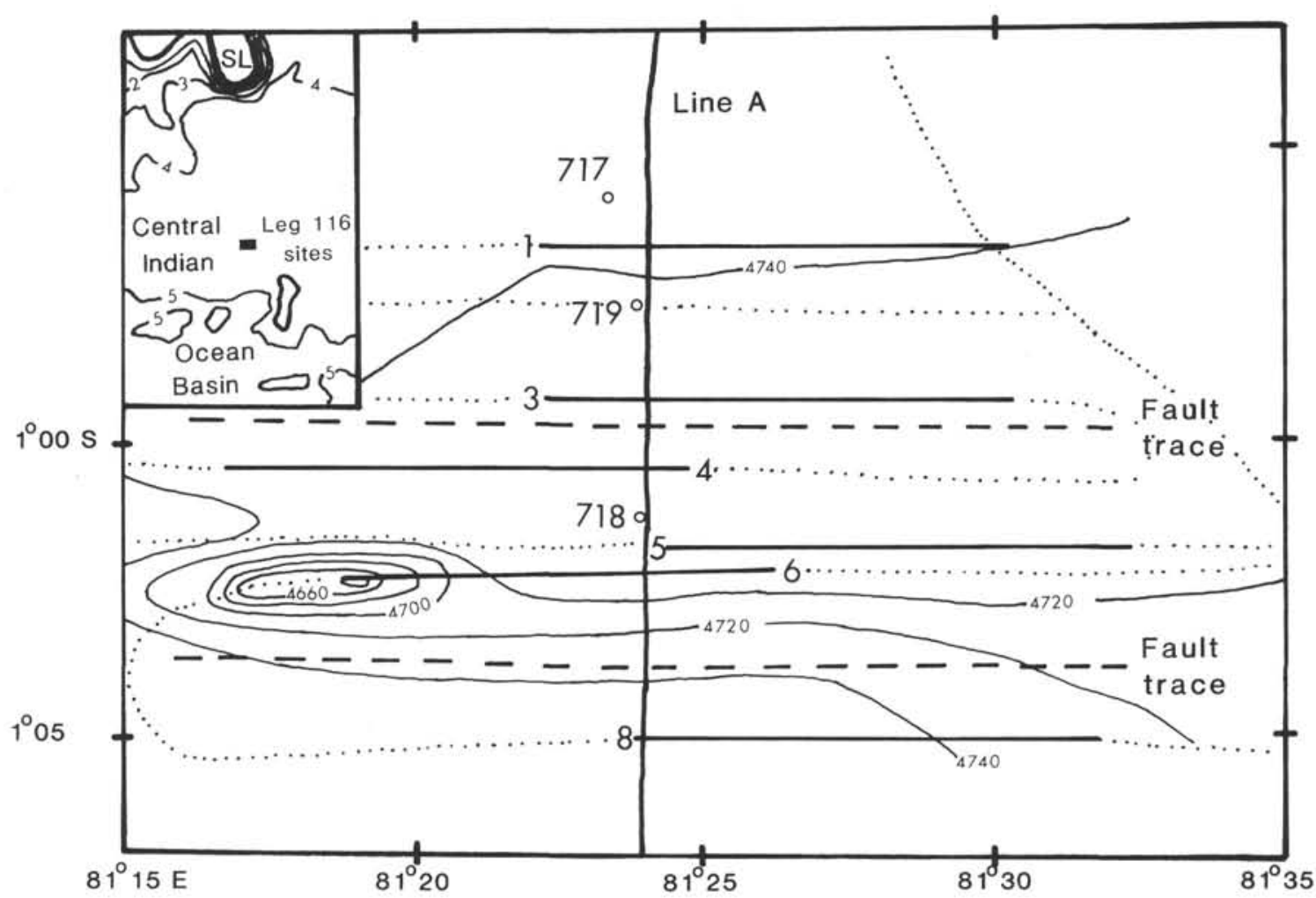

Figure 1. The local setting of the sonobuoy profiles. Bold straight lines indicate sonobuoy profiles, dotted lines the positions of the Charles Darwin 28 track lines, dashed lines the trace of the principal faults and the thin solid lines the bathymetry. Line $\mathrm{A}$ is drawn to show the line of the depth-converted section shown in Figure 2.

Table 1. Summary of interval velocities and thicknesses determined from the wide-angle profiles. Within each layer the numbers refer, left to right, to the interval velocity $(\mathrm{km} / \mathrm{s})$, the thickness $(\mathrm{km})$, the two-way traveltimes $(\%)$ below the seafloor to the bottom of the layer and the standard deviation of the traveltimes from the T2-X2 plot.

\begin{tabular}{|c|c|c|c|c|c|c|}
\hline $\begin{array}{l}\text { S/b Layer } \\
\text { * Lat } \\
\text { Long }\end{array}$ & 1 & 2 & 3 & & 4 & 5 \\
\hline $1_{8122.0 \mathrm{E}}^{0056.6 \mathrm{~S}}$ & 1.80 .120 .140 .02 & 2.10 .420 .540 .14 & \multicolumn{3}{|c|}{2.551 .781 .870 .04} & 4.10 .241 .990 .13 \\
\hline $3_{8122.2 \mathrm{E}}^{0059.3 \mathrm{~s}}$ & \multicolumn{5}{|c|}{2.21 .61 .450 .10} & $\begin{array}{l}\text { No velocity } \\
\text { determined }\end{array}$ \\
\hline $4 \begin{array}{r}0100.5 \mathrm{~S} \\
8124.6 \mathrm{E}\end{array}$ & \multicolumn{2}{|c|}{2.00 .350 .350 .09} & 2.50 .91 .160 .03 & \multicolumn{2}{|c|}{3.30 .81 .640 .11} & 4.10 .411 .840 .46 \\
\hline 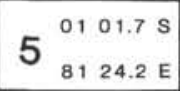 & \multicolumn{5}{|c|}{$2.21 .88 \quad 1.70 .24$} & 4.10 .342 .060 .4 \\
\hline 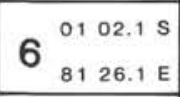 & \multicolumn{5}{|c|}{4.10 .348 .190 .40} & $\begin{array}{l}\text { No velocity } \\
\text { determined }\end{array}$ \\
\hline $88_{8123.8 \mathrm{E}}^{0105.0 \mathrm{~s}}$ & 2.20 .330 .410 .01 & 2.10 .150 .550 .02 & $2.50 .681 .05 c$ & & No veloc & ty determined \\
\hline
\end{tabular}

top of layer 3. No refracted arrivals were recorded from within layer 2 or from below the top of layer 3. A composite crustal velocity structure incorporating reflection, refraction, and ODP well data (Cochran, pers. commun.) is shown in Figure 4. The fitted line is biased toward the well data close to the surface, although the two sets of results are not in great disagreement. There is, nevertheless, frequently some lack of agreement between velocity data calculated from well logs and from sonobuoy profiles. It seems likely that sonobuoy reduction tends to overestimate velocities in the near surface $(1.7-1.8 \mathrm{~km} / \mathrm{s}$ to $1.6-1.7 \mathrm{~km} / \mathrm{s}$ here) where the sonobuoy data invariably average over the top few hundred meters. 


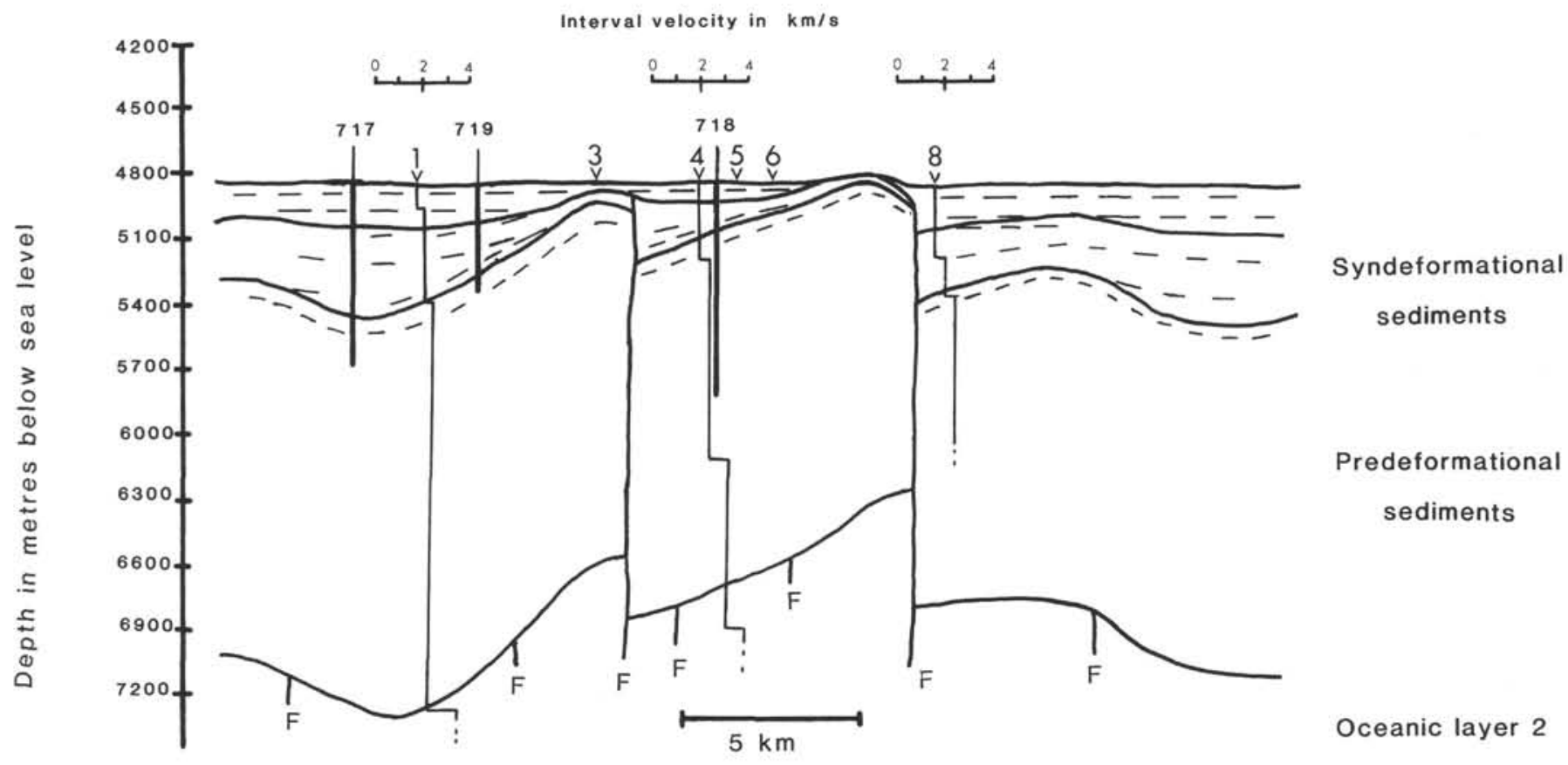

Figure 2. Depth-converted section along line A in Figure 1 close to the positions of the ODP drill sites. The time section was depth converted using a simple velocity function for instantaneous velocity $V$ at a depth $H: V=1.73+0.75 H$. The positions of the sonobuoy stations and drill sites are shown together with the velocity structure deduced from three of the wide-angle profiles.

\section{DISCUSSION}

\section{Sediment Velocity Structure}

The sediment velocities obtained here are in reasonable agreement with the limited amount of sonobuoy data published from this area (Naini and Leyden, 1973; Hamilton et al., 1974; Curray et al., 1982; Stein and Weissel, in press). Although generally consistent with a gradually consolidating turbiditic lithology to basement, it is likely that prior to the large-scale development of the Bengal Fan (pre-mid Miocene-the ' 0 ' sediments of Curry and Moore, 1971) a greater proportion of the sediment was pelagic chalks and clays. The jump in interval velocity from 2.5 to $3.3 \mathrm{~km} / \mathrm{s}$ at $1250 \mathrm{mbsf}$ on sonobuoy 4 may represent the presence of these pelagics toward the bottom of the sediment sequence. As sonobuoy 4 gave the best-quality record, and given the uniform lateral character on the vertical incidence reflection profiles of the pre-deformational sediment sequence, it is likely that data quality prevented this event from being seen on the other records. The depth to the base of the fan sediments is, however, uncertain as there are no discrete reflectors present on the wide-angle profiles below about $1300 \mathrm{mbsf}$.

The average sediment velocity gradient above basement of $0.75 / \mathrm{s}$ compares well with velocity gradients in deep-ocean sediment sequences measured elsewhere. Houtz et al. (1970) using results from several hundred sonobuoy stations in the North Pacific have found average velocity gradients of 0.6 $0.8 / \mathrm{s}$. Hamilton et al. (1974) present a regression equation based on variable angle reflections from sonobuoys in the Bay of Bengal, Bering Sea, Japan Sea, and North Pacific which predicts a decrease in average linear velocity gradient from $1.3 / \mathrm{s}$ at the surface to $0.8 / \mathrm{s}$ at a depth of $1000 \mathrm{mbsf}$. Bachman et al. (1983) give a near-surface velocity gradient for the southern Bengal Fan of 1.18/s. The ODP sonic log data suggest a near-surface gradient of about $1.2 / \mathrm{s}$, in excellent agreement with this. Our average gradient must incorporate these high values but also low values close to the basement, possibly no more than $0.25 / \mathrm{s}$ at $1500-2000 \mathrm{mbsf}$. Again, these low values may be more representative of sediments dominated by pelagic components.

\section{Basement Topography and Structure}

An interesting question in this area of intraplate deformation concerns the scale of topography on the oceanic basement: to what extent is it original and to what extent is it deformation related? The velocity data now available allow us to calculate basement depth. The amount of pre-deformation topography has been estimated along line A (Fig. 1) by calculating the thickness of pre-deformation sediment and assuming that the pre-deformation seafloor was flat. The simple velocity gradient used suggests that the thickness of pre-deformation sediment varies within fault blocks by $400 \mathrm{~m}$ and by up to $400 \mathrm{~m}$ between fault blocks. As mentioned earlier, no significant velocity contrast was detected across the onset of deformation between syn- and pre-deformation sediments-as would be expected as there is no gross change in lithology-so variations in syn-deformation sediment thickness should not affect the estimate of original topography. However, some of the variation in sediment thickness may arise from deviation from the simple velocity gradient used, furthermore it is possible that by, say, 1500 mbsf the velocity gradient is significantly lower than the $0.753 / \mathrm{s}$ used in the depth conversion. This would tend to reduce our estimate of pre-deformation topography to something closer to the abyssal hill topography of $100-300 \mathrm{~m}$ amplitude and 5-10 km wavelength commonly observed in the Pacific (Luyendyk, 1970; Macdonald and Luyendyk, 1985). The Pacific was chosen for comparison because both oceanic crusts were produced at relatively high spreading rates of about $6 \mathrm{~cm} / \mathrm{yr}$. We conclude from this that the topography observed is entirely consistent with deformation having affected an oceanic basement of normal topographic characteristics, in agreement with Shipboard Scientific Party (1989).

A weak reflector just below the top of oceanic layer 2 allowed an interval velocity of $4.1 \mathrm{~km} / \mathrm{s}$ to be calculated for the top layer of oceanic layer 2 for sonobuoys 4 and 5 . This result 


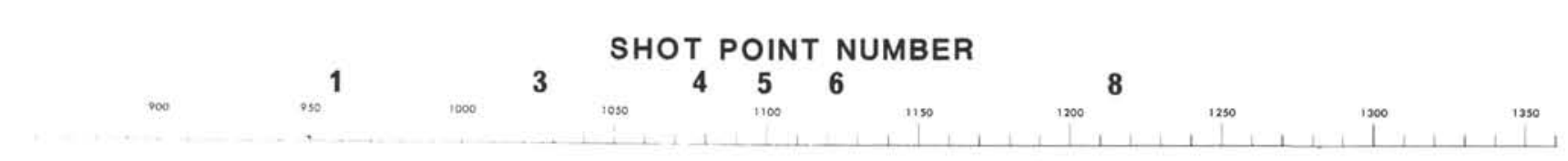

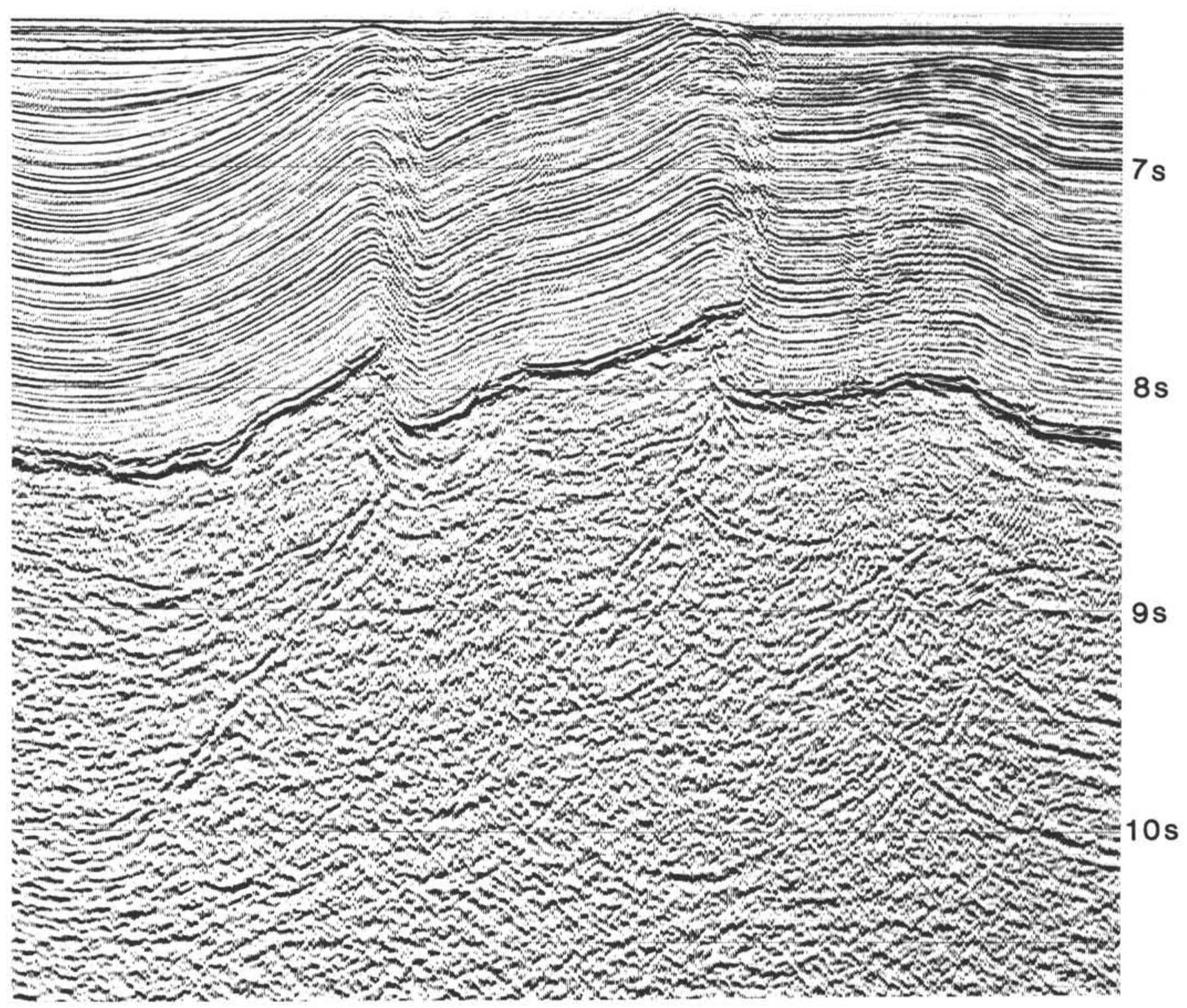

\section{$5 \mathrm{~km} \longrightarrow$}

Figure 3. A section of fully processed and migrated 12-channel, 12-fold multichannel profile from north (left) to south (right) through the ODP Leg 116 Sites and perpendicular to the structural grain (located A in Fig. 1). Bold numbers above the shot-point numbers indicate the positions of the sonobuoy stations. Vertical exaggeration is about 3:1 in the sediments and 1.5:1 to $2: 1$ in basement (the top of which is marked by the strong reflector at around $8 \mathrm{~s}$ ). Details of the high-angle fault planes in the sediments are evident: some anastomose and show curvature, some are just developing, and some are mature. The fault planes on which the displacement has taken place dip at $30^{\circ}$ to $40^{\circ}$ in basement and can be traced to depths around $10 \mathrm{~s}$ two-way traveltime (about Moho depth). The multichannel profiles are nearly perpendicular to the strike of the faults and therefore this apparent dip should be close to the true dip. Originally these faults may have been formed at the mid-ocean ridge to the south in which case they must have been outward-dipping faults.

is confirmed by refracted arrivals of $4.0-4.1 \mathrm{~km} / \mathrm{s}$ from this region. At first sight these appear to be low values for oceanic basement velocities, especially as in adjacent areas to the north, values in the range of 4.4-5.1 km/s have been reported (Curray et al., 1982; Neprochnov et al., 1988). However, these results are in good agreement with those of Houtz and Ewing
(1976) and the sonobuoy results of White (1979) from other areas of similar basement age and we agree with their prognosis of an origin in layer $2 \mathrm{~A}$. On the CD 28 wide-angle profiles the layer $2 \mathrm{~A} / 2 \mathrm{~B}$ interface was not defined by refractions and we have no evidence of the velocity at the top of layer $2 \mathrm{~B}$. 
Seismic velocity $[\mathbf{k m} / \mathbf{s}]$

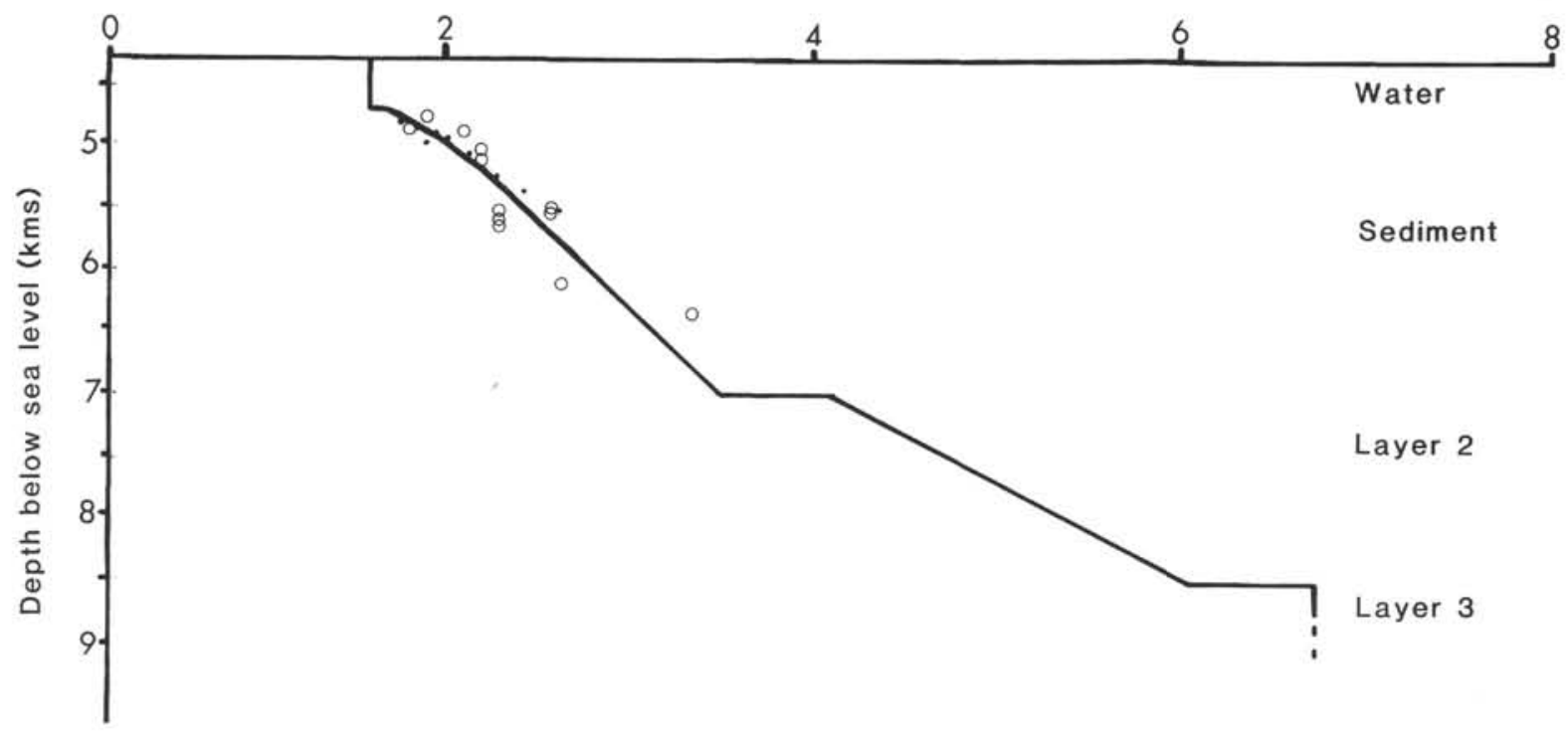

Figure 4. A composite velocity structure for the area around the ODP sites, incorporating well (dots), reflection (circles), and refraction data.

Refractions from the top of layer 3 with velocity $6.8-6.9$ $\mathrm{km} / \mathrm{s}$ were present from most of the sonobuoys. Typically layer 3 refractions will appear as first arrivals, but their strong presence, even on sonobuoy records of modest quality, suggests that the layer 2 /layer 3 boundary is well defined in this area. To calculate the thickness of layer 2 and the depth to the top of layer 3 , it has been assumed that the layer $2 \mathrm{~A}$ velocity of about $4.1 \mathrm{~km} / \mathrm{s}$ is underlain by a velocity gradient in layer 2 . The velocity gradient is poorly constrained in our data, but by assuming a gradient of $0.7 / \mathrm{s}$ (White, 1979; White and Matthews, 1980) an estimate for the thickness of layer 2 of about $1.5 \mathrm{~km}$ can be obtained. The only other estimates of layer 2 thickness in this area are those of Neprochnov et al (1988), who record values of 1.3-1.6 km, and Stein (1984) who state a thickness of $2 \mathrm{~km}$. These thicknesses of $1.3-2.0 \mathrm{~km}$ are fairly typical for oceanic layer 2 world-wide (Bott, 1982) and appear in no way anomalous as a result of the intraplate deformation. Neprochnov et al. (1988) suggest that beneath the crest of one of the deformation highs in this area, oceanic layer 2 is anomalously thin.

We have no direct information on the total thickness of the crust in the area of the drill sites. However, there is some indirect evidence that the crust might be thinner than normal. If the effects of sediment loading in the vicinity of the Leg 116 sites are removed by backstripping according to the method of Sclater and Christie (1980) it is found that unloaded basement is generally deeper than that predicted by Parsons and Sclater's plate cooling model (1977) (assuming a crustal age of $78 \mathrm{Ma}$ for the drill sites). There is an average residual depth anomaly of $-300 \mathrm{~m}$ which increases southward to as much as $-500 \mathrm{~m}$ at $4^{\circ}-5^{\circ} \mathrm{S}$. There may be a small contribution to this negative depth anomaly from the flexural response of the Indo-Australian Plate to loading by the Bengal Fan to the north, however this is likely to be at least an order of magnitude less than the observed anomaly. This would seem to leave two possible explanations: either it is associated with the intraplate deformation or it can be explained in terms of simple Airy isostatic compensation of a thin crust. Because the intraplate deformation is compressive in nature, one would intuitively expect shortening to produce a positive depth anomaly-the opposite of what is observed, we favor the latter hypothesis. White and McKenzie (1989) infer variations in oceanic crustal thickness due to random fluctuations in ambient asthenospheric potential temperature at the spreading center. Using crustal and mantle densities of 2.9 and $3.3 \mathrm{~g} / \mathrm{cm}^{3}$, respectively, and a normal crustal thickness of $6 \mathrm{~km}$, a residual depth anomaly of $-300 \mathrm{~m}$ requires a thinning of about $1.7 \mathrm{~km}$. Thus, we may suggest on the basis of residual depth anomalies that the crust is thin, but specifically that layer 3 is thinner than normal because above we commented on the fact that layer 2 appears to have a normal thickness.

\section{CONCLUSIONS}

The crustal velocity structure around the Leg 116 aites is broadly similar to that found elsewhere in the central Indian Ocean Basin. We find an average velocity gradient for the sediments of $0.753 / \mathrm{s}$, although the gradient close to the surface $(<400 \mathrm{~m})$, as revealed by the ODP velocity logs, is much higher-up to $1.2 / \mathrm{s}$ - and near basement it is probably much lower-about $0.25 / \mathrm{s}$. Near surface the sediment velocity is about $1.6 \mathrm{~km} / \mathrm{s}$, increasing to $3.4-3.5 \mathrm{~km} / \mathrm{s}$ immediately above basement. These higher velocity sediments may have a significant pelagic component.

Depth conversion of a seismic reflection profile through the drill sites shows that there was pre-deformation topography on basement reminiscent of the normal abyssal hill topography found developed in the Pacific.

A compressional wave velocity of $4.1 \mathrm{~km} / \mathrm{s}$, typical of layer $2 \mathrm{~A}$, was found for the top of oceanic layer 2 and assuming a velocity gradient of $0.7 / \mathrm{s}$ an estimate of $1.5 \mathrm{~km}$ for the thickness of this layer was obtained, which is normal.

Good quality refractions were obtained from the top of layer 3. Although there is no direct evidence of the thickness of layer 3, residual depth anomalies are consistent with it being anomalously thin. 


\section{ACKNOWLEDGMENTS}

The authors would like to thank the master, officers, and crew of the Charles Darwin and the technical staff of RVS Barry without whose expertise at sea this paper would not have been possible. We also thank Maya Tolstoy for early help in reduction of the records. This work was supported by NERC grant GR3/6480.

\section{REFERENCES}

Bachman, R. T., Hamilton, E. L., and Curray, J. R., 1983. Sediment sound velocities from sonobuoys: Sunda Trench and forearc basins, Nicobar and central Bengal Fans, and Andaman Sea Basins. J. Geophys. Res., 88:9341-9346.

Bott, M.H.P., 1982. The Interior of the Earth: Its Structure, Constitution and Evolution (2nd ed.): London (Edward Arnold).

Curray, J. R., and Moore, D. G., 1971. Growth of the Bengal DeepSea Fan and denudation of the Himalayas. Geol. Soc. Am. Bull., 82:563-572.

Curray, J. R., Emmel, F. J., Moore, D. G., and Raitt, R. W., 1982. In Nairn, A.E.M. and Stehli, F. G. (eds.), The Ocean Basins and Margins (Vol. 6): The Indian Ocean: New York, (Plenum Press), 399-450.

Hamilton, E. L., 1974. Sediment velocities from Sonobuoys: Bay of Bengal, Bering Sea, Japan Sea and North Pacific. J. Geophys. Res., 79:2653-2688.

Houtz, R. E., and Ewing, J. I., 1976. Upper crustal structure as a function of plate age. J. Geophys. Res., 81:2490-2498.

Houtz, R. E., Ewing, J. I., and Buhl, P., 1970. Seismic data from sonobuoy stations in the northern and equatorial Pacific. $J$. Geophys. Res., 73:2615-2641.

Le Pichon, X., Ewing, J. I., and Houtz, R. E., 1968. Deep sea sediment velocity determination made while reflection profiling. $J$. Geophys. Res., 73:2597-2614.

Luyendyk, B. P., 1970. Origin and history of abyssal hills in the northeast Pacific. Geol. Soc. Am. Bull., 81:2237-2260.
Macdonald, K. C., and Luyendyk, B. P., 1985. Investigation of faulting and abyssal formation on the flanks of the East Pacific Rise. Mar. Geophys. Res., 7:515-535.

Naini, B. P., and Leyden, R., 1973. Ganges cone: a wide-angle seismic reflection and refraction study. J. Geophys. Res., 78:8711-8720.

Neprochnov, Y. P., Levchenko, O. V., Merklin, L. R., and Sedov, V. V., 1988. The structure and tectonics of the intraplate deformation area in the Indian Ocean. Tectonophysics, 156:89-106.

Parsons, B., and Sclater, J. G., 1977. An analysis of the variation of ocean floor bathymetry and heat flow with age. J. Geophys. Res., 82:803-827.

Sclater, J. G., and Christie, P.A.F., 1980. Continental stretching: an explanation of the post-mid-Cretaceous subsidence in the Central North Sea Basin. J. Geophys. Res., 85:3711-3739.

Shipboard Scientific Party, 1989. Site 116. In Cochran, J. R., Stow, D.A.V., et al., Proc. ODP, Init. Repts., 116: College Station, TX (Ocean Drilling Program).

Stein, C. A., 1984. Part 1-Heat transfer, seismicity and intraplate deformation in the central Indian Ocean [Ph.D. dissert.]. Columbia Univ., New York.

Stein, C. A., and Weissel, J. K., in press. Constraints on central Indian Ocean Basin thermal structure from heat flow, seismicity and bathymetry. Tectonophysics.

White, R. S., 1979. Oceanic upper crustal structure from variable angle seismic reflection-refraction profiles. J. Geophys. Res., 57:683-726.

White, R. S., and Matthews, D. R., 1980. Variations in oceanic upper crustal structure in a small area of the north-eastern Atlantic. Geophys. J. R. Astron. Soc., 61:401-435.

White, R. S. and Mckenzie, D. P., in press. Magmatism at rift zones: the generation of volcanic continental margins and flood basalts. $J$. Geophys. Res.

Date of initial receipt: 13 April 1989

Date of acceptance: 30 November 1989

Ms 116B-155 